\title{
THE DEVELOPMENT OF VIRTUAL LABORATORY LEARNING MEDIA FOR THE PHYSICAL OPTICS SUBJECT
}

\author{
Arif Billah*1, Arif Widiyatmoko $^{2}$ \\ ${ }^{1}$ Institut Agama Islam Negeri (IAIN) Salatiga, Indonesia \\ ${ }^{2}$ Graduate student of Graduate School for International Development and Cooperation, Hiroshima University, Japan \\ *corresponding author: arifbillahbadr@iainsalatiga.ac.id
}

Received: July $2^{\text {nd }}, 2018$. Accepted: October $21^{\text {st }}, 2018$. Published: October $28^{\text {th }}, 2018$

\begin{abstract}
This study aims to produce virtual laboratory interactive learning media that is effective and practical for the subject of physical optics. It uses the Research and Development $(R \& D)$ method. The material in the learning media includes dispersion, diffraction, interference, and polarization. Users of this product can be directly involved in observing, measuring and taking practical data. Product development has been validated by material expert, media expert, and practitioners (teachers). This product has also been tested in one-to-one, small groups, and field trial. Based on the results of the assessment by material expert, media expert, teachers, and field trial, this learning media software is categorized as "excellent" with a value of 4.63 for validity, "medium" with an $n$-gain value of 0.37 for effectiveness, and "excellent" with a value of 4.49 for practicality.
\end{abstract}

(C) 2018 Physics Education, UIN Raden Intan, Lampung, Indonesia

Keywords: learning media, physical optics, virtual laboratory

\section{INTRODUCTION}

Physics as a branch of natural science basically aim to study and provide information about laws, theories, principles, facts from various natural phenomena. Common constraints in physics learning are that students required to master concepts, formulas and calculations, graphs and diagrams, and practicum presented simultaneously (Liliarti \& Kuswanto, 2018).

The aforementioned learning process is strongly supported by the activities in the laboratory. Experimental physics learning: (1) is a core component of physics as a discipline (Wilcox \& Lewandowski, 2018); (2) can train student skills in problem-solving in accordance with learning in the classroom (Danielsson, 2014); and (3) can increase the activity and learning outcomes of physics (Poniman, 2016). Physics experiment activities also make teachers able to observe student learning behavior in paying attention, understanding concepts, understanding procedural instructions, and measuring experimental results (Purba \& Hwang, 2018). Thus, physics experiments or practicum contributes to realize a successful physics learning. The success of learning activities in this laboratory must be supported by the selection of the right tools and materials (Bernhard, 2018).

Based on the results of observations in the field, the supporting components of laboratory-based physical optics learning are still inadequate. This observation was carried out in five high schools in the Semarang City of Indonesia. The low level of physics learning activities especially the subject of laboratory-based physical optics is due to (1) inadequate equipment availability; (2) unavailability of materials; (3) lack of laboratory personnel at schools; (4) longer working time in labs compared to the time for conventional learning; and (5) difficulties in visualizing abstract physics concepts. 


\section{THEORETICAL FRAMEWORK}

Limitations and constraints on the use of laboratories as a place for experimental activities or practicum can be solved by using other learning strategies, one of which is to use computer media. Computers can be used as learning support media because they are able to do: (1) simultaneous presentation, processing, and calculation of data (text, numeric, image, audio, visual); (2) program data into interactive and animated simulations. This potential is very supportive in the development of teaching aids and physics learning media in the form of multimedia software containing audio, visual, simulation, and interactive animation.

The use of computer simulations contributes positively to the success of physics learning (Amadeu \& Leal, 2013); Virtual lab experience and computerbased visualization allow students to interact with scientific concepts that are difficult to observe directly (Chiu, Dejaegher, \& Chao, 2015); it makes learning interesting and allows students to actively manipulate graphical visualization of complex phenomena (Moser, Zumbach, \& Deibl, 2017); and provides opportunities for students to plan, organize, and control learning with a high level of flexibility (Arista \& Kuswanto, 2018). Modeling and simulation of laboratory experiments can help students overcome obstacles in cost (Ahmed \& Hasegawa, 2014), time, and security (Kurniawati \& Fatisa, 2016). Through interviews, students positively think about their experiences in virtual lab-based learning (Aşiksoy \& Islek, 2017).

The positive impact of computer use as a physics experimental media simulation (virtual lab), among others, is able to: (1) improve students' ability to understand basic science (Escobar, Sánchez, Beltrán, La Hoz, \& González, 2016); (2) improve students' abilities in planning and implementing problem solving solutions (Gunawan, Harjono, Sahidu, \& Herayanti, 2017); (3) improve scientific literacy skills(Jannati, Setiawan, Siahaan, \& Rochman, 2018); (4) support distance learning (González, Escobar, Sánchez, De La Hoz, \& Beltrán, 2017); (5) make practical activities cheaper and can help teachers explain the concept of electronic circuits (Emhadelima, 2015); and (6) make learning time more efficient, support independent learning, and can be used to measure mastery of material (Masril, Hidayati, \& Darvina, 2018). The students stated that they were learning faster, more interesting and fun (Ünlü \& Dökme, 2015).

Based on the field study and the literature above, it is necessary to develop a Virtual Laboratory Learning Media for Physical Optics. Researchers chose the subject of physical optics because in this material, there are several abstract concepts and facts from field studies.

\section{METHOD}

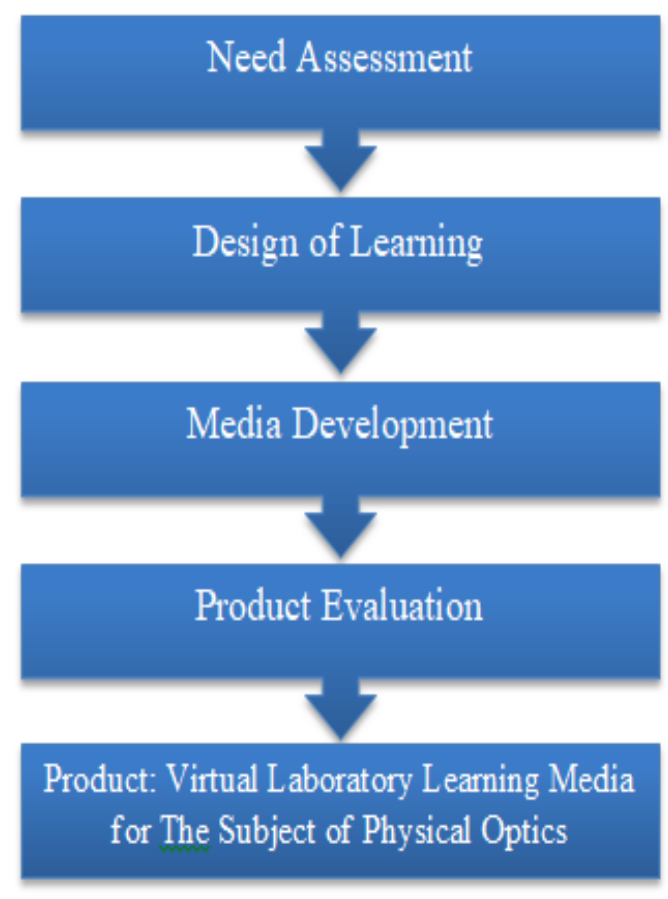

Figure 1. Development Procedure of Virtual Laboratory Learning Media for the Subject of Physical Optics. 
This type of research is Research and Development ( $\mathrm{R} \& \mathrm{D})$, therefore this research is product oriented. The product developed was in the form of Virtual Laboratory Learning Media for Physical Optics for high-school students of XII grade. The development procedure in this study is explained in Figure 1.

The data obtained are qualitative and quantitative data. Qualitative data is obtained from questionnaires given to material experts, media experts, teachers and students. The number of students involved was three students at the one-toone test stage, 12 students in the smallgroup test stage, 38 students for the experimental group, and 38 students for the control group.

Qualitative data is used to obtain the validity and practicality of the product. Quantitative data is obtained from test scores in the form of multiple choices. Quantitative data is needed to test the effectiveness of product implementation. The instruments used were questionnaires, interview guides, student activity observation sheets, and test questions. The research data is also sourced from suggestion notes about product quality.

The quantitative data analysis technique used in this study is descriptive statistics with the criteria of "excellent", "very good", "good", "fair", and "poor" which are converted into quantitative data on a scale of 5 starting from 1 up to 5 . The steps in analyzing data include: (a) collecting raw data, (b) scoring, and (c) conversions shown in Table 1.

Table 1. Assessment criteria

\begin{tabular}{ccc}
\hline Value & Criteria & Value Interval \\
\hline A & Excellent & $\mathrm{X}>(\mathrm{Xi}+1.8 \mathrm{Sbi})$ \\
B & Very & $(\mathrm{Xi}+0.6 \mathrm{Sbi})<\mathrm{X} \leq(\mathrm{Xi}+1.8 \mathrm{Sbi})$ \\
Good & Good & $(\mathrm{Xi}-0.6 \mathrm{Sbi})<\mathrm{X} \leq(\mathrm{Xi}+0.6 \mathrm{Sbi})$ \\
D & Fair & $(\mathrm{Xi}-1.8 \mathrm{Sbi})<\mathrm{X} \leq(\mathrm{Xi}-0.6 \mathrm{Sbi})$ \\
E & Poor & $\mathrm{X} \leq(\mathrm{Xi}-1.8 \mathrm{Sbi})$ \\
\hline
\end{tabular}

The indicators of the success of product research developed are: (1) valid if the results of the evaluation from the validate get the minimum criteria of "good"; (2) effective if the $\mathrm{N}$-gain value is in the "medium" category; and (3) the practical results of the validate's assessment obtained at least "good" criteria.

\section{RESULTS AND DISCUSSION Results}

The contents of this product are not only for virtual laboratory applications but also for providing theoretical material equipped with images, animations, and videos. It aims to enable students to learn independently. Virtual laboratories are designed to be interactive virtual laboratory simulations so students can be directly involved in observation, measurement, and data collection of virtual lab results.

The main menu contains Learning Objectives, Materials, Virtual labs, and Evaluations. The main material consists of: (1) Dispersion, (2) Diffraction, (3) Interference, and (4) Polarization. In each material menu, there are sub menus: (1) Introduction, (2) Materials, Simulations, (4) Videos, and (5) Quizzes. Examples of this page display are shown in Figure 2.

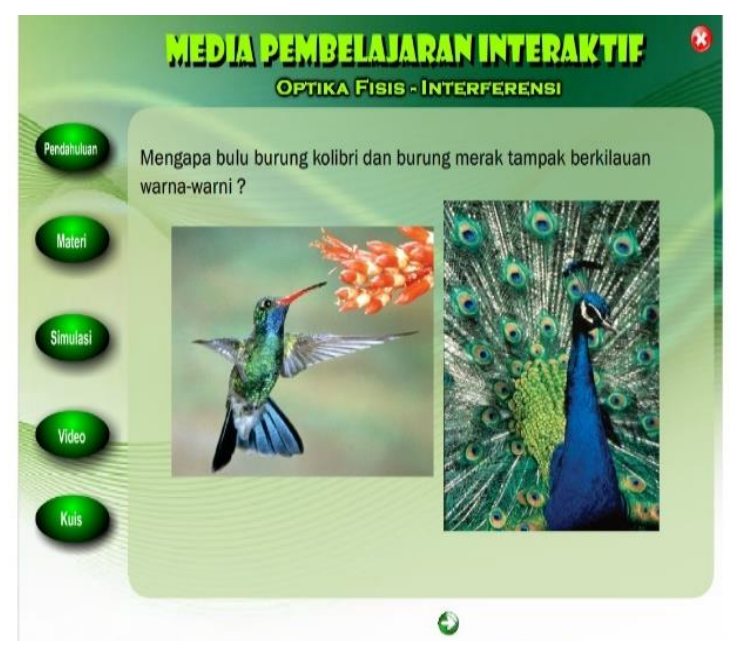

Figure 2. The display of the material menu 
The virtual laboratory menu contains (1) Light Dispersion on the Prism, (2) Single-Slit Diffraction, and (3) Double Slit Interference (Top View), and (4) Double Slit Interference (Side View). An example of a virtual laboratory page is shown in Figure 3.

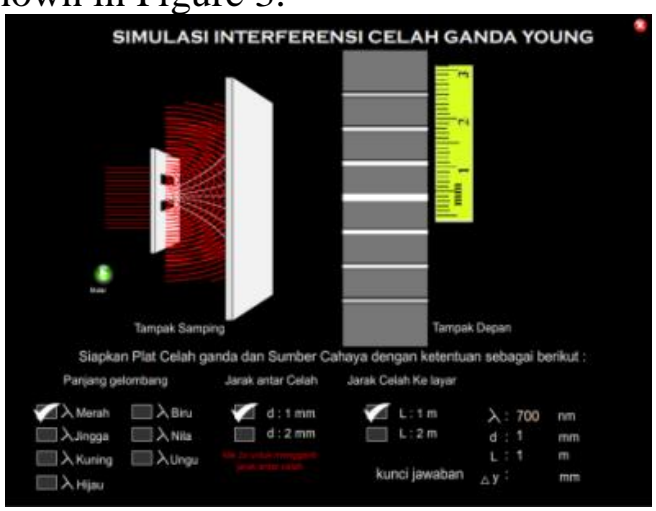

Figure 3. Virtual Laboratory page for Double slit Interference

Evaluation contains two random questions. Each package has 20 multiplechoice questions. The opening page for evaluation is shown in Figure 4.

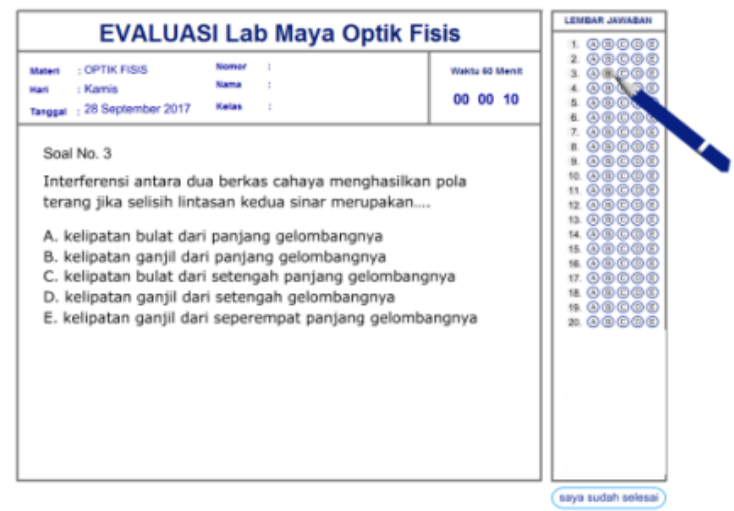

Figure 4. Evaluation Opening Page

The average pre-test, post-test, $\mathrm{N}$-gain values of the one-to-one and small-group trials are shown in Table 2.

Table 2. Results of one-to-one and small group trials

\begin{tabular}{cccc}
\hline Group & Pre-test & $\begin{array}{c}\text { Post- } \\
\text { test }\end{array}$ & n-gain \\
\hline One-to-one & 3,33 & 16,67 & $\begin{array}{c}0,80 \\
(80,41 \%)\end{array}$ \\
\hline Small group & 3,00 & 13,67 & $\begin{array}{c}0,63 \\
(63,35 \%)\end{array}$ \\
\hline
\end{tabular}

The mean values of the pre-test, posttest, and n-gain of the experimental and control groups are shown in Table 3.

Table 3. Field test results

\begin{tabular}{cccc}
\hline Group & Pre-test & $\begin{array}{c}\text { Post- } \\
\text { test }\end{array}$ & n-gain \\
\hline Experiment & 3,29 & 13,34 & $\begin{array}{c}0,37 \\
(36,94 \%)\end{array}$ \\
\hline Control & 3,16 & 10,39 & $\begin{array}{c}0,27 \\
(26,54 \%)\end{array}$ \\
\hline
\end{tabular}

The average n-gain of the experimental group and the control group in the medium category. This data is shown in Figure 5.

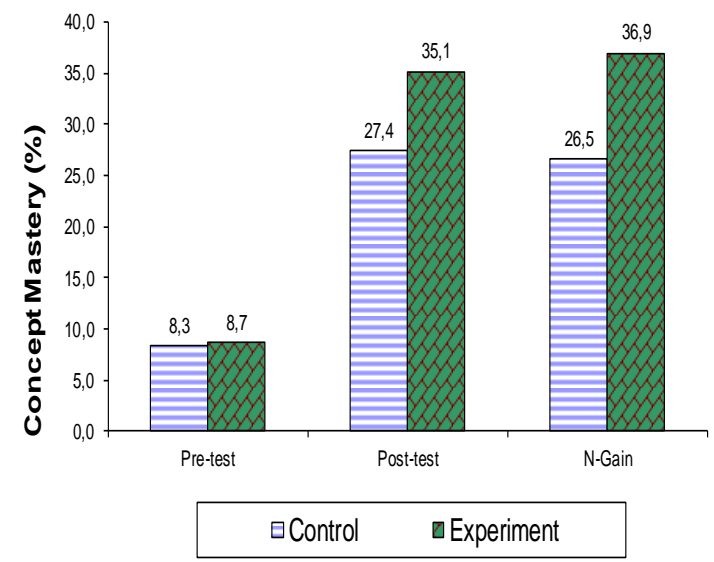

Figure 5. Comparison of Average Scores of Pre-test, Post-test, and N-gain Concept Mastery for Both Groups

The results of the normality test are shown in Table 4.

Table 4. The resultof the normality test of data

\begin{tabular}{cccc}
\multicolumn{4}{c}{ concept mastery } \\
\hline Group & $\boldsymbol{\chi}_{\text {count }}^{2}$ & $\chi_{\text {table }}$ & Conclusion \\
\hline Experiment: & 2.111 & 7.815 & $\begin{array}{c}\text { Normally } \\
\text { distributed } \\
\text { N-gain }\end{array}$ \\
$\begin{array}{c}\text { Control: } \\
\text { N-gain }\end{array}$ & 1.058 & 7.815 & $\begin{array}{c}\text { Normally } \\
\text { distributed }\end{array}$ \\
\hline
\end{tabular}

The homogeneity test is carried out using the $\mathrm{F}$ test (equation of two variants). This data is shown in Table 5.

Table 5. The result of the homogeneity test of data concept mastery

\begin{tabular}{ccccc}
\hline $\begin{array}{c}\text { Variance of } \\
\text { Experimental } \\
\text { Group }\end{array}$ & $\begin{array}{c}\text { Variance } \\
\text { of } \\
\text { Control } \\
\text { Group }\end{array}$ & $\mathbf{F}_{\text {count }}$ & $\mathbf{F}_{\text {table }}$ & Conclusion \\
\hline 103.05 & 102.08 & 1.01 & 1.85 & $\begin{array}{l}\text { The sample } \\
\text { variance is in a } \\
\text { homogeneous state }\end{array}$ \\
\hline
\end{tabular}


The technique used in this hypothesis test is a parametric statistical technique ( $\mathrm{t}-$ test). This is because the data from both groups are normal and homogeneously distributed. The results of the hypothesis test analysis are shown in Table 6.

Table 6. The hypothesis test results of student concept mastery with t-test one tail of both groups

\begin{tabular}{lllll} 
Aspect & $\mathbf{S}$ & $\mathbf{t}_{\text {count }}$ & $\mathbf{t}_{\text {table }}$ & Conclusion \\
\hline N-gain & 11.447 & 0.009 & 1.6657 & $\begin{array}{l}\text { Hypothet Ho } \\
\text { accepted }\end{array}$ \\
\hline
\end{tabular}

Table 6 shows that the results of hypothesis testing with a one-way t-test (t-tailed) are $t_{\text {count }}<t_{\text {table. }}$ This shows that there are significant differences between new and old teaching methods. New teaching methods are more effective than old teaching methods.

The results of the product validity assessment are shown in Table 7.

Table 7. Results of product validity assessment

\begin{tabular}{clcc}
\hline \multicolumn{1}{c}{ Aspects } & Validators & Values & Criteria \\
\hline \multirow{2}{*}{$\begin{array}{l}\text { Feasibility } \\
\text { of content }\end{array}$} & $\begin{array}{l}\text { Material } \\
\text { expert }\end{array}$ & 4.60 & Excellent \\
\cline { 2 - 4 } & Teacher & 4.88 & Excellent \\
\hline \multirow{2}{*}{$\begin{array}{l}\text { Feasibility } \\
\text { of } \\
\text { presentation }\end{array}$} & $\begin{array}{l}\text { Material } \\
\text { Expert }\end{array}$ & 4.30 & Excellent \\
\cline { 2 - 4 } & Teacher & 4.74 & Excellent \\
\hline \multicolumn{2}{c}{ Average } & 4.63 & Excellent \\
\hline
\end{tabular}

The results of the product practicality assessment are shown in Table 8.

Table 8. The product practicality assessment results

\begin{tabular}{llcc}
\hline \multicolumn{1}{c}{ Aspects } & \multicolumn{1}{c}{ Validators } & Values & Criteria \\
\hline $\begin{array}{l}\text { Quality and } \\
\text { reliability }\end{array}$ & $\begin{array}{l}\text { Media } \\
\text { expert }\end{array}$ & 4.73 & Excellent \\
\cline { 2 - 4 } Ease of Use & $\begin{array}{l}\text { Teacher } \\
\text { expert }\end{array}$ & 4.76 & Excellent \\
\cline { 2 - 4 } & Teacher & 4.18 & $\begin{array}{c}\text { Very } \\
\text { good }\end{array}$ \\
\hline Design/shape & $\begin{array}{l}\text { Media } \\
\text { expert }\end{array}$ & 4.00 & $\begin{array}{c}\text { Excellent } \\
\text { geod }\end{array}$ \\
\cline { 2 - 4 } & Teacher & 4.80 & Excellent \\
\hline Influence on & $\begin{array}{l}\text { Media } \\
\text { expert }\end{array}$ & 4.00 & $\begin{array}{c}\text { Very } \\
\text { good }\end{array}$ \\
\cline { 2 - 4 } & Teacher & 4.90 & Excellent \\
\hline \multicolumn{2}{c}{ Average } & 4.49 & Excellent \\
\hline
\end{tabular}

\section{Discussion}

Interactive multimedia-based virtuallearning lab in this study combines several elements of interactive simulation, learning material, and evaluation. The products resulted from this study are packaged in interactive learning CDs that can be run directly or can be installed. This product can function as an independent learning media.

The average value given by material experts and teachers on the validity of the product is 4.63 . Based on the results of this assessment, it can be concluded that the product meets the validity criteria with the criteria of "excellent". The average value given by media experts and teachers on product practicality is 4.49 . Based on the results of this assessment, it can be concluded that the product meets the practical criteria with the criteria of "excellent".

The results of the product assessment through the one-to-one test are "excellent", there is an average increase in the post-test score. This is indicated by a normalized gain of 0.8 or $80.41 \%$, so it can be concluded that the increase in mastery of concepts at the one-to-one test stage is in the "high" category.

The results of product assessment through small-group tests are "excellent", indicated by a normalized gain of 0.63 or $63.35 \%$, so it can be concluded that the increase in mastery of concepts in smallgroup tests is in the "medium" category.

In the field trial stage, in the experimental group, the product obtained a "high" category with a normal gain of 0.37 or $36.94 \%$, so it can be concluded that the increase in mastery of the concepts in this test was "medium", while the control group, without using the product, the normalized gain value is 0.27 or $26.54 \%$. Based on the description, it can be concluded that the product of this study is effective.

In the research data, the experimental group shows that through the help of this 
product students easily understand difficult and abstract concepts, as well as physical optical material and this product, can be used anywhere and anytime. This is because the product is equipped with interactive simulations and animations that can visualize abstract concepts that become more concrete so that the learning process becomes more meaningful for students.

The characteristics that are the hallmarks of this product are: (1) Learning objectives, materials, labs, and evaluations have been integrated into a single software package; (2) Material contains the initial menu, description of material, simulation, video, and quiz; (3) The introductory menu can be used as apperception learning and pre-test; (4) Material is described through full text and color images to attract students' attention; (5) Simulation in the form of interactive and communicative moving images; (6) In the material menu. There are videos about material and laboratory reviews; (7) The teacher can use it as a learning media, which includes pre-test, post-test, and evaluation; (10) Students can use it as an independent learning material and can repeat any sections of the learning material they want; and (11) This virtual laboratory can be used anywhere and anytime.

While the weaknesses of this product are: (1) cannot display objects in 3D; (2) can only run on Microsoft Windows operating systems; and (3) no usage history.

Data from the mastery of students' concepts in the experimental and control groups were obtained from evaluations using the same problem as many as 20 items. The mean pre-test values in the experimental and control groups were $8.7 \%$ and $8.3 \%$. It means there is no difference in the mastery of concepts between the two groups before the application of the product. This is because the two groups were evenly distributed, and the two groups had never received similar learning.

Both groups were given different treatments. The experimental group uses products, and the control group uses lecture learning. The mean value of the post-test experimental group was $35.1 \%$, and the control group was $27.4 \%$. This shows a significant difference in the mastery of physical optics concepts. The $\mathrm{N}$-gain value of the experimental group was $36.9 \%$ with the category "medium" and for the control group was $26.5 \%$ with the category "low". Thus, mastery of the concept of the experimental group students with the application of virtual lab products is higher than the control group.

The results of the observation showed that students in the experimental group were happier, more enthusiastic, more creative and motivated. Observation data indicates that students' curiosity increased, as evidenced by the increasing activity of expressing ideas, opinions, or very dominant questions, namely $93.1 \%$. This proves that the application of products in learning has increased student learning motivation.

Another thing that was found during the observation was that the teacher's role declined in learning. So, the teacher plays the role as a facilitator, directs and motivates students in learning. In the control group, it was found that student enthusiasm tended to be lower than the experimental group, this was seen in expressing opinions, asking questions, or doing practical activities.

The most significant difference between the two groups is the duration of lab activity. During the learning process, the experimental group took less time than the control group. This shows that the use of media virtual lab learning is more efficient in terms of time. Based on the description above, it can be concluded that the use of virtual lab learning media on the subject of physical optics is more effective and efficient. 
Learning by using this product can improve the mastery of students' concepts. The virtual lab learning media can visualize abstract concepts more concretely so that the learning objectives and learning processes become more meaningful. With meaningful learning, students will achieve learning outcomes that are more optimal or better than before.

\section{CONCLUSION}

Based on the results of the study, it can be concluded that the product development in the form of virtual lab learning media on the subject of physical optics is (1) valid, the average value is 4.63 with the category "excellent"; (2) effective, $\mathrm{N}$-gain from the experimental group, which is 0.37 or $36.94 \%$ with the category "medium"; and (3) practical, the average value is 4.49 with the category "excellent".

\section{REFERENCES}

Ahmed, M. E., \& Hasegawa, S. (2014). An Instructional Design Model and Criteria for Designing and Developing Online Virtual Labs, 4(3), 355-371.

Amadeu, R., \& Leal, J. P. (2013). Advantages of using computer simulations in physics learning. Enseñanza de Las Ciencias, 31(3), 177-188. Retrieved from http://www.rieoei.org/deloslectores/1 640Carrio.pdf

Arista, F. S., \& Kuswanto, H. (2018). Virtual physics laboratory application based on the Android smartphone to improve learning independence and conceptual understanding. International Journal of Instruction, 11(1), 1-16.

Aşiksoy, G., \& Islek, D. (2017). The impact of the virtual laboratory on students' attitudes in a general physics laboratory. International Journal of Online Engineering,
13(4), 20-28.

Bernhard, J. (2018). What matters for students' learning in the laboratory? do not neglect the role of experimental equipment! Instructional Science. https://doi.org/10.1007/s11251-0189469-x

Chiu, J. L., Dejaegher, C. J., \& Chao, J. (2015). The effects of augmented virtual science laboratories on middle school students' understanding of gas properties. Computers and Education, 85, 5973.

Danielsson, A. T. (2014). In the physics class: University physics students' enactment of class and gender in the context of laboratory work. Cultural Studies of Science Education, 9, 477-494.

Emhadelima. (2015). The use of virtual media laboratory to increase students' motivation on direct current circuits materials at class $\mathrm{X}$ of MAN I Pekanbaru. Al-Ta'lim Journal, 22(3), 254-265.

Escobar, J. H., Sánchez, H., Beltrán, J. R., La Hoz, J. De, \& González, J. D. (2016). Virtual experimentation in electromagnetism, mechanics, and optics: Web-based learning. Journal of Physics: Conference Series, 687(1).

González, J. D., Escobar, J. H., Sánchez, H., De La Hoz, J., \& Beltrán, J. R. (2017). 2D and 3D virtual interactive laboratories of physics on Unity platform. Journal of Physics: Conference Series, 935(1).

Gunawan, Harjono, A., Sahidu, H., \& Herayanti, L. (2017). Virtual laboratory to improve students' problem-solving skills on electricity concept. Jurnal Pendidikan IPA Indonesia, 6(2), 257-264.

Jannati, E. D., Setiawan, A., Siahaan, P., \& Rochman, C. (2018). Virtual laboratory learning media 
development to improve science literacy skills of mechanical engineering students on basic physics concept of material measurement. Journal of Physics: Conference Series, 1013(1).

Kurniawati, Y., \& Fatisa, Y. (2016). Evaluasi Program Pemodelan Dan Simulasi Laboratorium Kimia Pada Mahasiswa Calon Guru. Edusains, 8(2), 201-211.

Liliarti, N., \& Kuswanto, H. (2018). Improving the competency of diagrammatic and argumentative representation in physics through Android-based mobile learning application. International Journal of Instruction, 11(3), 106-122.

Masril, M., Hidayati, H., \& Darvina, Y. (2018). The Development of Virtual Laboratory Using ICT for Physics in Senior High School. IOP Conference Series: Materials Science and Engineering, 335(1).

Moser, S., Zumbach, J., \& Deibl, I. (2017). The effect of metacognitive training and prompting on learning success in simulation-based physics learning. Science Education, 101(6), 944-967.

Poniman. (2016). Upaya Peningkatan Aktivitas dan Hasil Belajar Fisika dengan Metode Praktikum pada Siswa Kelas XI IPA MAN 1 Kalianda Lampung Selatan. Jurnal Ilmiah Pendidikan Fisika Al-Biruni, 05(2), 257-264.

Purba, S. W. D., \& Hwang, W. Y. (2018). Investigation of learning behaviors and achievement of simple pendulum for vocational high school students with Ubiquitous-Physics app. Eurasia Journal of Mathematics, Science and Technology Education, 14(7), 2877-2893.

Ünlü, Z. K., \& Dökme, İ. (2015). 7th Grade Students' Views on Combining the use of Computer Simulations and Laboratory
Activities in Science Teaching. Procedia - Social and Behavioral Sciences, 191, 1173-1177.

Wilcox, B. R., \& Lewandowski, H. J. (2018). A Summary of researchbased assessment of students' beliefs about the nature of experimental physics. American Association of Physics Teachers. 